\title{
CLINICAL SCIENCES
}

\section{COMPARATIVE STUDY OF THE LOCKED INTRAMEDULLARY NAIL AND ENDER PINS IN THE TREATMENT OF TIBIAL DIAPHYSEAL FRACTURES}

\author{
Marcos Hideyo Sakaki, Alberto Tesconi Crocci, Arnaldo Valdir Zumiotti
}

\begin{abstract}
Sakaki MH, Crocci AT, Zumiotti AV. Comparative study of the locked intramedullary nail and Ender pins in the treatment of tibial diaphyseal fractures. CLINICS. 2007;62(4):455-64.
\end{abstract}

OBJECTIVE: To compare the locked, unreamed intramedullary nail with Ender pins in the treatment of open Gustilo grade I or II or closed tibial diaphyseal fractures of type A, B, or C2 of the AO classification.

MATERIALS AND METHODS: Forty-four patients with unilateral tibial diaphyseal fractures were treated with intramedullary nails or Ender pins. Twenty patients were treated with an unreamed intramedullary nail with access via the patellar tendon with static locking. Twenty-four patients were treated with Ender pins introduced medially and laterally with respect to the tuberosity of the tibia. The main parameters analyzed were type of reduction, complications, union rate, deformities, joint mobility, pain, gait, effort capacity, presence of neurovascular disorders, and complaints related to the synthesis material.

RESULTS: During 1 year of follow-up, the fractures of $90.0 \%$ of the patients with intramedullary nails and $95.7 \%$ of patients with Ender pins healed within an average of 21.5 weeks and 20.9 weeks, respectively. The significant findings were as follows: patients treated with Ender pins had less mobility of the subtalar joint; patients treated with intramedullary nails were more likely to have pain in the knee; both groups showed shortening of the tibia at the end of 1 year of treatment.

CONCLUSIONS: The two methods are similar in the treatment of type A, B, and C2 tibial diaphyseal fractures.

KEY WORDS: Fracture fixation, intramedullary. Tibial fractures/surgery. Bone nails. Orthopedic fixation devices. Follow-up studies.

\section{INTRODUCTION}

The osteosynthesis of a tibial diaphyseal fracture with a locked intramedullary nail (LIN) is recommended by various authors due to the high union rates, low infection and deformity rates, and good functional results. ${ }^{1-7}$

However, up to $79 \%$ of patients need complementary procedures for certain complications. ${ }^{8}$ Pain in the knee is a frequent complication in $22 \%$ to $71 \%$ of the cases, ${ }^{9-11}$ and breaking of the screws in unreamed locked nails occurs in up to $52 \%$ of cases with early weight bearing. ${ }^{12}$

The comparison of LIN and Ender pins demonstrates that the latter results in less blood loss, surgery time, and

Department of Orthopedics and Traumatology, Faculty of Medicine, University of São Paulo, São Paulo/SP, Brazil.

Received for publication on June 17, 2007

Accepted for publication on June 27, 2007 hospitalization time. ${ }^{13}$ However, some reports have noted that Winquist IV type fractures are not adequately treated with this type of synthesis due to poor axial stability. ${ }^{14,15}$

The objective of this study was to compare LIN with Ender pins, which are less expensive in our market, for type $\mathrm{A}, \mathrm{B}$, or $\mathrm{C} 2$ tibial diaphyseal fractures according to the $\mathrm{AO}$ classification.

\section{CASE DESCRIPTIONS AND METHODOLOGY}

Forty-four patients with tibial diaphyseal fractures underwent surgery at the Orthopedics and Trauma Institute at the Hospital das Clínicas of the University of São Paulo Medical School between March 2000 and September 2001. They were divided into 2 groups: 24 patients were treated with Ender pins (Ender group), and 20 were treated with unreamed, locked intramedullary nails (LIN group). 
The case descriptions of both groups were analyzed according to the parameters age, sex, fracture side, trauma mechanism, occurrence of fibular fracture, associated lesions, and classifications according to AO group, ${ }^{16}$ Tscherne, ${ }^{17}$ and Gustilo. ${ }^{18}$ There were no significant differences regarding these parameters. (Table 1).

The following inclusion criteria were adopted: closed fracture with Tscherne type 0,1 , or 2; open fracture with Gustilo degree I or II; simple fracture or partial, multifragmented fracture of type A, B, or C2 of the AO Group classification; patient aged 16 to 70 ; unilateral tibial fracture having occurred within 4 weeks of surgery; tibial diaphyseal fracture with indication for surgical treatment (translational dislocation of the fracture larger than $50 \%$ of the diaphyseal diameter, shortening greater than 1 centimeter, unsatisfactory reduction with plaster device with varus and valgus angular deviations greater than 5 degrees, with antecurvation and recurvation deviations greater than 10 degrees and rotational deviations greater than 10 degrees).

Any factors not in the inclusion list were considered exclusion factors.

All patients participating in the study were informed about the study conditions, objectives, advantages and risks, and about the possible treatment options if participation was not chosen. All study patients or those legally responsible for them signed a consent agreement.

The patients included in the study were hospitalized and underwent collection of clinical and radiographic data for the purpose of classifying lesions to soft tissue according to the criteria of Tscherne and Gustilo, and of the fracture according to the $\mathrm{AO}$ group criteria.

The selection of the implant used for osteosynthesis of the tibial fracture was randomized according to the registration number that the patient received when hospitalized. When the number was even, fixation was executed with Ender pins, and when it was odd, with a locked intramedullary nail.

Patients with exposed fractures underwent cleaning of the wound with saline solution and surgical debridement, with collection of material for culture. Definitive setting of the fracture was performed during the same surgery in patients with exposed fractures that occurred less than 6 hours beforehand. If this was not the case, only debridement was performed, the patient was maintained with inguino-podalic cast, and bandages were changed daily until the fracture was fixed. Additional debridement sessions were performed in individual cases when necessary.

Closed fractures and unfixed open fractures were submitted to intramedullary nailing, preferably in the first week. Prophylactic antibiotic therapy was performed with 1 gram of intravenous cephazolin, begun upon starting anesthetic induction and repeated every 8 hours for 48 hours. Patients with exposed Gustilo type I fractures received the same antibiotic, this was started upon hospitalization and maintained for 14 days, while those with exposed Gustilo type II fractures received $500 \mathrm{mg}$ of intravenous amikacin every 12 hours with $600 \mathrm{mg}$ of intravenous clindamycin every 6 hours, also for 14 days.

Table 1 - Descriptions of both groups according to age, sex, fracture, side, trauma mechanism, and classifications

\begin{tabular}{|c|c|c|c|c|c|}
\hline Parameter & & Ender & LIN & Statistical Test & $P$ \\
\hline \multirow[t]{3}{*}{ Age (Years) } & Mean & 31.46 & 34.30 & MannWhitney & 0.44 \\
\hline & SD & 10.94 & 13.19 & & \\
\hline & SEM & 2.23 & 2.95 & & \\
\hline \multirow[t]{2}{*}{$\operatorname{Sex}(n, \%)$} & Male & $21(87.5)$ & $19(95.0)$ & Fisher & 0.61 \\
\hline & Female & $3(12.5)$ & $1(5.0)$ & & \\
\hline \multirow[t]{2}{*}{ Side $(\mathrm{n}, \%)$} & Right & $16(66.7)$ & $13(65.0)$ & Fisher & 1.00 \\
\hline & Left & $8(33.3)$ & $7(35.0)$ & & \\
\hline \multirow[t]{2}{*}{ Trauma mechanism (n, \%) } & High energy $^{1}$ & $22(91.7)$ & $15(75.0)$ & Fisher & 0.22 \\
\hline & Low energy $^{2}$ & $2(8.3)$ & $5(25.0)$ & & \\
\hline \multirow[t]{2}{*}{ Fíbula fracture (n, \%) } & Absent & $2(8.3)$ & $2(10.0)$ & Fisher & 1.00 \\
\hline & Present & $22(91.7)$ & $18(90.0)$ & & \\
\hline \multirow[t]{2}{*}{ Associate lesions (n, \%) } & Absent & $15(62.5)$ & $11(55.0)$ & chi-square & 0.85 \\
\hline & Present $^{3}$ & $9(37.5)$ & $9(45.0)$ & & \\
\hline \multirow[t]{2}{*}{ AO classification (n, \%) } & Type A & $11(45.8)$ & $9(45.0)$ & chi-square t & 0.80 \\
\hline & Types B and C & $13(54.2)$ & $11(55.0)$ & & \\
\hline \multirow[t]{2}{*}{ Tscherne classification (n, \%) } & Types 0 and 1 & $13(54.2)$ & $9(45.0)$ & Fisher & 0.37 \\
\hline & Type 2 & $2(8.3)$ & $4(20.0)$ & & \\
\hline \multirow[t]{2}{*}{ Gustilo classification(n, \%) } & Type I & $5(20.8)$ & $5(25.0)$ & Fisher & 0.63 \\
\hline & Type II & $4(16.7)$ & $2(10.0)$ & & \\
\hline
\end{tabular}

Elder $=$ Elder pin procedure LIN $=$ locked intramedullary nail procedure

NOTE: $n .=n .=$ number of cases; 1 -includes automotive accident and running over; 2 -includes fall, labor and sport accident. 3-includes lower extremity fracture, knee ligament lesion, upper extremity frcture, spine fracture, costal fracture and brain injury. 
Access pathways for placing Ender pins were created in the proximal region of the leg on the tibial condyles. Two incisions of about $3 \mathrm{~cm}$ each, one medial and the other lateral to the tuberosity of the tibia, were used, exposing the tibial condyles, which were easily identified after subcutaneous opening. Two bone orifices, with an area of approximately $0.5 \mathrm{~cm}^{2}$, were perforated with a broach, one in each tibial condyle about $3 \mathrm{~cm}$ from the articular surface, so as to allow the introduction of an Ender pin in each orifice. Pins were introduced to fill the space of the medullar canal at its narrowest part, with a minimum of 2 pins used (1 lateral and 1 medial). The fractures were reduced preferably by indirect methods, and the pins were advanced inside the distal fragment and positioned about $2 \mathrm{~cm}$ above the talocrural joint, with diverging ends (Figure 1).

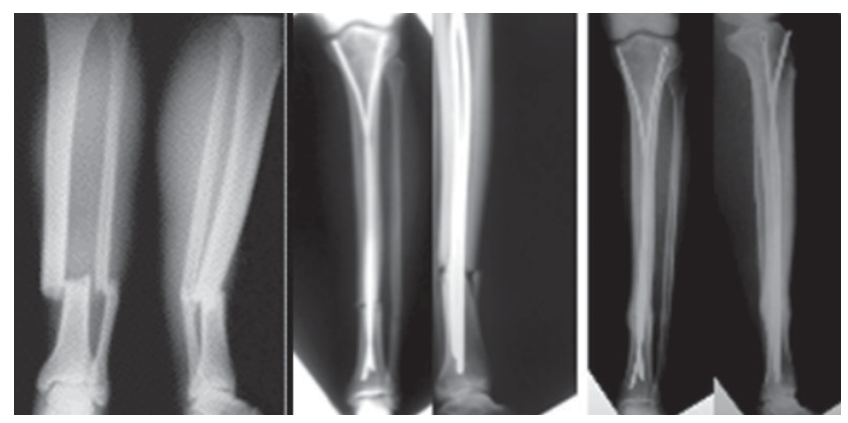

Figure 1 - Appropriate technique for using Ender pins. Proper positioning of the pins provides sufficient stability for union and prevents proximal migration.

The access pathway created for osteosynthesis with a locked intramedullary nail was straight in the anterior knee, extending from the distal pole of the patella to the tibial tuberosity.

Patients in both groups were maintained on a short cast for 14 days. The operated limb was relieved of weight for the first 4 weeks after surgery and then allowed partial weight with crutches until union. Radiographs were taken monthly until union and at the end of 1 year. When a fracture did not evolve toward union for more than 3 consecutive months during ambulatory follow-up, the patient underwent another surgery; patients in the Ender group were treated with bone grafting, and those in the LIN group with dynamization of fixation with the removal of proximal or distal locks at the fracture point. The final evaluation (radiograph and functional) was made after 1 year of postoperative evolution in all cases.

The following parameters were studied: type of reduction performed, immediate postoperative deformities, complications, new operations performed, union, deformities after 1 year of treatment (final), joint mobility, pain, gait, effort capacity, presence of neurovascular disturbances, and complaints related to the synthesis material, with evalua- tion of results according to Johner and Wruhs. ${ }^{16}$

The deformities studied were shortening, rotational, and angulation in the sagittal and frontal planes. The first two were measured clinically and the last in verification radiographs. Malunion was defined as varus or valgus deformity greater than 5 degrees, antecurvation or recurvation deformity grater than 10 degrees, rotational deformity greater than 10 degrees, and shortening greater than 1 centimeter. ${ }^{16}$

A new surgery was defined as any surgical procedure performed after setting of the tibia that was deemed necessary due to some local complication or to contribute to the bone union process.

The union criterion adopted was the presence of at least 3 healed cortices seen in 2 radiographs (front and lateral), in addition to the absence of pain and mobility at the fracture point. ${ }^{7}$

The degree of mobility of the knee joint, of the ankle, and of the talocalcaneal joint (subtalar) was observed during a physical exam performed at the end of 1 year of follow-up and was expressed as a percentage in comparison to the normal side.

The presence of pain was evaluated at the end of 1 year of follow-up, and was classified as absent; occasional when it was infrequent; unpredictable, and not requiring analgesics; moderate when it always occurred when the patient performed some action (such as climbing stairs) or required the use of analgesics; and severe when it occurred even at rest.

The quality of gait 1 year after surgery was identified as normal or altered. When altered, this parameter was separated into small limp when perceptible only during a detailed clinical exam of gait and large limp when easily noted when the patient entered the clinic.

The ability to use the leg with effort after 1 year of follow-up was considered normal or altered. When normal, the patient was able to climb stairs normally, and when altered this parameter was divided into limited when unable to climb stairs, very limited when unable to walk at least 100 meters, and impossible when unable to walk without assistance.

The evaluation of the results at the end of 1 year of follow-up was based on the criteria defined by Johner and Wruhs, ${ }^{16}$ which include union rate; neurovascular disturbances; deformities; knee, ankle and subtalar joint mobility; and pain, gait, and effort capacity (Table 2). Four groups were defined as follows: excellent, good, fair, and poor, with the worst result among all criteria evaluated defining the group to which the patient belongs.

Descriptive statistics were used to describe the quantitative samples, with calculation of the mean, standard deviation, and the standard error of the mean. Qualitative sample data were described using a frequency and proportion distribution. 
Table 2 - Tibia fracture classification scheme (Johner and Wruhs, 1983)

\begin{tabular}{|c|c|c|c|c|}
\hline & Excellent & Good & Regular & $\mathrm{Bad}$ \\
\hline $\begin{array}{l}\text { Pseudarthrosis, } \\
\text { ostitis, amputation }\end{array}$ & absent & absent & absent & present \\
\hline $\begin{array}{l}\text { Neurovascular } \\
\text { disturbance }\end{array}$ & absent & minimum & moderate & grave \\
\hline $\begin{array}{l}\text { Deformity in } \\
\text { frontal plane }\end{array}$ & absent & $\begin{array}{c}2-5 \\
\text { degrees }\end{array}$ & $\begin{array}{c}\text { 6-10 } \\
\text { degrees }\end{array}$ & $\begin{array}{c}>10 \\
\text { degrees }\end{array}$ \\
\hline $\begin{array}{l}\text { Deformity in } \\
\text { sagittal plane }\end{array}$ & $\begin{array}{c}0-5 \\
\text { degrees }\end{array}$ & $\begin{array}{c}6-10 \\
\text { degrees }\end{array}$ & $\begin{array}{c}11-20 \\
\text { degrees }\end{array}$ & $\begin{array}{c}>20 \\
\text { degrees }\end{array}$ \\
\hline Rotational deformity & $\begin{array}{c}0-5 \\
\text { degrees }\end{array}$ & $\begin{array}{c}\text { 6-10 } \\
\text { degrees }\end{array}$ & $\begin{array}{c}11-20 \\
\text { degrees }\end{array}$ & $\begin{array}{c}>20 \\
\text { degrees }\end{array}$ \\
\hline Shortening & $0-5 \mathrm{~mm}$ & $6-10 \mathrm{~mm}$ & $11-20 \mathrm{~mm}$ & $>20 \mathrm{~mm}$ \\
\hline Knee mobility & normal & $>80 \%$ & $>75 \%$ & $<75 \%$ \\
\hline Ankle mobility & normal & $>75 \%$ & $>50 \%$ & $<50 \%$ \\
\hline Subtalar mobility & $>75 \%$ & $>50 \%$ & $<50 \%$ & \\
\hline Pain & absent & occasional & moderate & grave \\
\hline Walk & normal & normal & $\begin{array}{c}\text { claudication, } \\
\text { light }\end{array}$ & $\begin{array}{c}\text { claudication, } \\
\text { grave }\end{array}$ \\
\hline Heavy activity & possible & limited & $\begin{array}{c}\text { adequate } \\
\text { but limited }\end{array}$ & impossible \\
\hline
\end{tabular}

The chi-squared test and Fisher's exact test were used to compare qualitative data parameters. The Mann Whitney $\mathrm{U}$ test and the Wilcoxon test were used to compare groups of quantitative data in the cases when data was related or not, respectively. In all cases, a significance level of 5\% \pm $=0.05)$ was adopted.

\section{RESULTS}

One patient in the Ender group was excluded from the evaluations performed after 1 year of follow-up because he required treatment for malunion by the Ilizarov method after 10 months of treatment.

Results are provided in Table 3. The patients treated with Ender pins had a larger average angular deviation in the sagittal plane than those treated with a locked nail, but the difference was not significant $(P=0.21$; Mann-Whitney test). Of the 9 patients with this type of deviation in the Ender group, $8(88.9 \%)$ had a recurvation deviation. Ender pins have 2 curvatures, one proximal and the other distal, and are introduced through orifices made in the anterior tibia. This positioning, with the concavity of the pins facing front, favors a recurvation deformity (Figure 2). Therefore, we believe that premodeling of the pin, partially rectifying the distal curve, may reduce the incidence of this deformity.

All patients studied recovered total knee and partial ankle mobility, without significant differences between the two groups. There was, however, a significant loss of subtalar mobility ( $P=0.04$; Mann-Whitney test) in the patients treated with Ender pins. The number of patients with pain

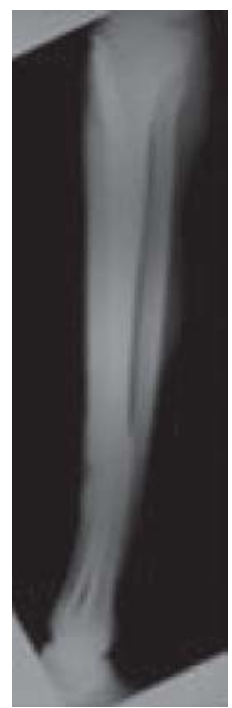

Figure 2 - Recurvation union in a fracture set with Ender pins. Note that the deformity coincides with the angle of the distal ends of the pins.

after 1 year of follow-up was similar in the Ender and LIN groups, but knee pain was more frequent in patients treated with LIN ( $P=0.02$; Fisher test). Discomfort due to synthesis material was present in 8 patients in the two groups (18.6\%). According to the Johner and Wruhs evaluation criteria, excellent or good results were found in 14 cases $(70,0 \%)$ of the LIN group and in 13 cases $(56,5 \%)$ of the Ender group ( $\mathrm{P}=0,53$; Fisher test).

The complications observed are listed in Table 4. and their incidence was not significantly different, but the larger number of infections in the LIN group was apparent: 2 superficial and 3 deep infections compared to only 1 superficial infection in the Ender group $(P=0.08$; Fisher exact test). All the cases were resolved solely with the use of antibiotic therapy, except for 1 patient in the LIN group who required removal of the synthesis material. The 6 cases resulted in an overall infection rate of $13.6 \%$, above the average rate found in the literature, which varies from $0 \%$ to $7 \%$. 2,3,5,6,12,14,19,30,33,34. The overall incidence of malunion was $15,9 \%$. Two cases $(10.0 \%)$ treated with locked nails evolved with breaking of the locking screws, but there was no breaking of pins in either the Ender group or the LIN group. Reflex sympathetic dystrophy was observed in 3 patients $(6,8 \%)$ and neurological lesions in $2(4,6 \%)$.

Three fractures in the study did not undergo union. One patient treated with Ender pins refused surgical treatment with bone grafts, and 2 patients in the LIN group had their fractures dynamized because union had not occurred by the end of 1 year. The general rate of pseudarthrosis was $6.8 \%$, with an average union time of 20.87 weeks in the Ender group and 21.50 weeks in the LIN group, similar to some reports in the literature..$^{5,19-21,29,34}$ 
Table 3 - Tabulation of the immediate postsurgical (ps) evaluation and 1-year (yr) follow-up results.

\begin{tabular}{|c|c|c|c|c|c|}
\hline \multicolumn{2}{|l|}{ Parameter } & \multirow{2}{*}{$\frac{\text { Ender }}{22(91.7)}$} & \multirow{2}{*}{$\frac{\mathrm{LIN}}{18(90.0)}$} & \multirow{2}{*}{$\begin{array}{c}\text { Statistical Test } \\
\text { Fisher exact }\end{array}$} & \multirow{2}{*}{$\frac{P}{1.00}$} \\
\hline Reduction & Direct & & & & \\
\hline type $(\mathrm{n}, \%)$ & Indirect & $2(8.3)$ & $2(10.0)$ & & \\
\hline Frontal plane & Mean & 2.25 & 1.70 & Mann-Whitney & 0.87 \\
\hline \multirow[t]{2}{*}{ angulation, ps } & SD & 3.18 & 1.95 & & \\
\hline & SEM & 0.65 & 0.46 & & \\
\hline \multirow{3}{*}{$\begin{array}{l}\text { Sagittal plane } \\
\text { angulation, ps }\end{array}$} & Mean & 2.04 & 0.60 & Mann-Whitney & 0.21 \\
\hline & SD & 3.10 & 1.27 & & \\
\hline & SEM & 0.63 & 0.24 & & \\
\hline \multirow{3}{*}{$\begin{array}{l}\text { Rotational } \\
\text { deformity, ps }\end{array}$} & Mean & 1.00 & 2.10 & Mann-Whitney & 0.58 \\
\hline & SD & 2.36 & 4.42 & & \\
\hline & SEM & 0.48 & 0.99 & & \\
\hline \multirow[t]{3}{*}{ Shortening, ps } & Mean & 1.17 & 2.35 & Mann-Whitney & 0.25 \\
\hline & SD & 5.72 & 4.89 & & \\
\hline & SEM & 1.17 & 1.09 & & \\
\hline \multirow{2}{*}{$\begin{array}{l}\text { Complications } \\
(\mathrm{n}, \%)\end{array}$} & Present & $11(45.8)$ & $10(50.0)$ & Chi-square & 0.98 \\
\hline & Absent & $13(54.2)$ & $10(50.0)$ & & \\
\hline \multirow{2}{*}{$\begin{array}{l}\text { New surgeries } \\
(\mathrm{n}, \%)\end{array}$} & Yes & $3(12.5)$ & $4(20.0)$ & Chi-square & 0.68 \\
\hline & No & $21(87.5)$ & $16(80.0)$ & & \\
\hline \multirow[t]{2}{*}{ Union (n, \%) } & Yes & $23(95.8)$ & $18(90.0)$ & Fisher exact & 0.58 \\
\hline & No & $1(4.2)$ & $2(10.0)$ & & \\
\hline \multirow[t]{3}{*}{ Union time } & Mean & 20.87 & 21.50 & Mann-Whitney & 0.95 \\
\hline & SD & 7.04 & 8.48 & & \\
\hline & SEM & 1.47 & 2.00 & & \\
\hline \multirow{3}{*}{$\begin{array}{l}\text { Frontal plane } \\
\text { angulation, 1-yr }\end{array}$} & Mean & 2.22 & 1.70 & Mann-Whitney & 0.54 \\
\hline & SD & 2.49 & 1.95 & & \\
\hline & SEM & 0.52 & 0.44 & & \\
\hline \multirow{3}{*}{$\begin{array}{l}\text { Sagittal plane } \\
\text { angulation, 1-yr }\end{array}$} & Mean & 1.48 & 0.60 & Mann-Whitney & 0.45 \\
\hline & SD & 2.57 & 1.27 & & \\
\hline & SEM & 0.54 & 0.29 & & \\
\hline Rotational & Mean & 2.09 & 2.75 & Mann-Whitney & 1.00 \\
\hline deformity, 1-yr & SD & 3.22 & 4.76 & & \\
\hline & SEM & 0.67 & 1.03 & & \\
\hline Shortening, 1-yr & Mean & 2.48 & 4.20 & Mann-Whitney & 0.52 \\
\hline & $\mathrm{SD}$ & 4.03 & 6.33 & & \\
\hline & SEM & 0.84 & 1.42 & & \\
\hline Knee mobility (\%) & Mean & 100.00 & 100.00 & Mann-Whitney & 1.00 \\
\hline & SD & 0.00 & 0.00 & & \\
\hline & SEM & 0.00 & 0.00 & & \\
\hline Ankle mobility (\%) & Mean & 93.91 & 93.00 & Mann-Whitney & 0.83 \\
\hline & SD & 9.41 & 14.90 & & \\
\hline & SEM & 1.96 & 3.33 & & \\
\hline Subtalar mobility (\%) & Mean & 77.39 & 94.00 & Mann-Whitney & 0.04 \\
\hline & SD & 27.17 & 11.42 & & \\
\hline & SEM & 5.67 & 2.55 & & \\
\hline Pain (n, \%) & present & $9(39.1)$ & $9(45.0)$ & Chi-square & 0.94 \\
\hline & Absent & $14(60.9)$ & $11(55.0)$ & & \\
\hline Pain in local & present & $7(30.4)$ & $2(10.0)$ & Fisher exact & 0.14 \\
\hline fracture $(n, \%)$ & Absent & $16(69.6)$ & $18(90.0)$ & & \\
\hline Knee pain $(n, \%)$ & Present & $1(4.3)$ & $7(35.0)$ & Fisher exact & 0.02 \\
\hline & Absent & $22(95.7)$ & $13(65.0)$ & & \\
\hline Ankle pain (n, \%) & Present & $7(30.4)$ & $2(10.0)$ & Fisher exact & 0.14 \\
\hline & Absent & $16(69.6)$ & $18(90.0)$ & & \\
\hline Walking quality & Normal & $18(78.3)$ & $16(80.0)$ & Fisher exact & 1.00 \\
\hline & Varied & $5(21.7)$ & $4(20.0)$ & & \\
\hline Capacity of stress & Normal & $19(82.7)$ & $17(85.0)$ & Fisher exact & 1.00 \\
\hline & Varied & $4(17.3)$ & $3(15.0)$ & & \\
\hline Neurovascular & Present & $0(0.00)$ & $0(0.00)$ & - & - \\
\hline disturbance & Absent & $23(100.00)$ & $20(100.00)$ & & \\
\hline Discomfort from & Present & $5(21.7)$ & $3(15.0)$ & Fisher exact & 0.70 \\
\hline pin and nail & Absent & $18(78.3)$ & $17(85.0)$ & & \\
\hline Johner; Wruhs & Excellent + good & $13(56.5)$ & $14(70.0$ & Fisher exact & 0.53 \\
\hline evaluation & Regular + Bad & $10(43.4)$ & $6(30.0)$ & & \\
\hline
\end{tabular}

Elder $=$ Elder pin procedure; $\mathrm{LIN}=$ locked intramedullary nail procedure $\mathrm{SD}=$ standard deviation; $\mathrm{SEM}=$ standard error of the mean 
Table 4 - Complications findings

\begin{tabular}{lcc}
\hline Complications & Ender & LIN \\
\hline Incorrect union & $4(16.7 \%)$ & $3(15.0 \%)$ \\
Loss of union & $2(8.3 \%)$ & $0(0.0 \%)$ \\
Superficial infection & $1(4.2 \%)$ & $2(10.0 \%)$ \\
Deep infection & $0(0.0 \%)$ & $3(15.0 \%)$ \\
Neurological lesion & $1(4.2 \%)$ & $1(5.0 \%)$ \\
Reflex sympathetic dystrophy & $2(8.3 \%)$ & $1(5.0 \%)$ \\
Deep vein thrombosis & $0(0.0 \%)$ & $1(5.0 \%)$ \\
Eschar & $1(4.2 \%)$ & $1(5.0 \%)$ \\
Broken screw & $0(0.0 \%)$ & $2(10.0 \%)$ \\
Union Malunion & $4(16.7 \%)$ & $3(15.0 \%)$ \\
\hline
\end{tabular}

Elder $=$ Elder pin procedure LIN = locked intramedullary nail procedure Substituição do termo da tabela 4 página 28 - De: Union addiction - Para: Malunion

Table 5 - Comparison of deformities immediately postsurgery vs at the 1-year follow-up

\begin{tabular}{lcccccc}
\hline Deformity & \multicolumn{3}{c}{ Ender } & \multicolumn{3}{c}{ LIN } \\
& Postsurgical & Final & $P$ & Postsurgical & Final & $P$ \\
\hline $\begin{array}{l}\text { Frontal plane } \\
\text { angulation (degrees) }\end{array}$ & 2.25 & 2.22 & 0.11 & 1.70 & 1.70 & 1.00 \\
$\begin{array}{l}\text { Sagittal plane } \\
\text { angulation (degrees) }\end{array}$ & 2.04 & 1.48 & 0.18 & 0.60 & 0.60 & 1.00 \\
$\begin{array}{l}\text { Rotational (degrees) } \\
\text { Shortening (mm) }\end{array}$ & 1.00 & 2.09 & 0.07 & 2.10 & 2.75 & 0.18 \\
\hline
\end{tabular}

Elder $=$ Elder pin procedure LIN = locked intramedullary nail procedure

The immediate postoperative deformities were compared with those observed after 1 year of follow-up (Table 5). Analyzing the parameters of the deformities present immediately after surgery and after 1 year of follow-up, we observed that both Ender pins $(P=0.02$; Wilcoxon test $)$ and the locked intramedullary nail $(P=0.04$; Wilcoxon test $)$ did not impede increased shortening. This fact is understandable in patients treated with Ender pins because the method does not provide axial stability in fractures with comminution, but was not expected in the group treated with LIN where the static lock prevents the collapse of the fracture, at least in theory. Shortening in 5 patients was due to fractures being dynamized due to breakage or surgery (Figure 3).

\section{DISCUSSION}

In both groups, there was a larger number of young patients (average age 32.75 years), males (90.9\%), and traffic accident victims $(84.1 \%)$. These findings are in accordance with the majority of studies related to tibial diaphyseal fractures ${ }^{1,4,19-28}$ and show the effect of a high level of

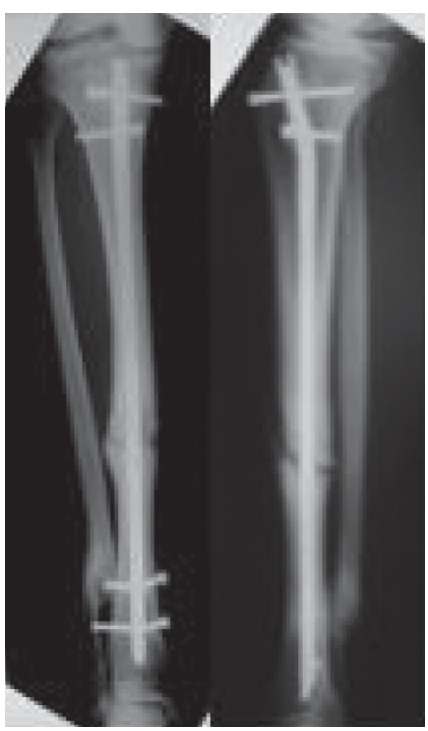

Figure 3 - Breakage of distal locking screws in an A2 type fracture, contributing to a significant shortening in the group treated with locked intramedullary nails.

violence in traffic affecting young people of working age.

Only fractures of types A, B, and $\mathrm{C} 2$ of the AO group in which both types of fixation-locked intramedullary nail and Ender pins - are considered efficient, were included in this study. ${ }^{1,5,13,21,29-32}$ We chose to include segmental tibial diaphyseal fractures (C2) based on the work of Merianos et al, ${ }^{30}$ who obtained union in all 22 cases treated with Ender pins, with an average union time of only 16 weeks. In the only study found in the literature that compares the locked intramedullary nail with Ender pins in the treatment of tibial diaphyseal fractures, ${ }^{13}$ the authors reported a longer union time in the group treated with Ender pins in Winquist type III and IV fractures, which have great instability. This finding contributed to the decision to study only less unstable fractures.

In the two groups, 7 patients $(15.9 \%)$ had malunion, a larger rate than that found in the literature, ${ }^{20,29,34-36}$ where the average was $5 \%$. It is important to clarify that of these 7 patients, 6 presented inadequate reduction, or in other words, left osteosynthesis surgery with deformities above acceptable limits, perhaps a result of technical difficulties in the reduction of these fractures. The other case of malunion occurred due to the breaking of the locking screws on the locked intramedullary nail, which led to significant shortening. A patient with a segmental fracture (type C2) treated with Ender pins presented malunion that required surgical correction via osteotomy and installation of the Ilizarov device after 10 months of treatment. This was the most serious complication that occurred during the study. Only 1 other case of segmental fracture was treated with Ender pins, and it resulted in union with good alignment. We were not able to reproduce the good results found by 
Merianos et $\mathrm{al}^{30}$ and believe that the use of Ender pins in a segmental fracture should be an exceptional treatment.

Breakage of locking screws is a frequent complication, ${ }^{25-}$ $27,34,35$ with rates reaching $52 \%$ when unreamed locked nails are used. ${ }^{12}$ No operations were performed to remove broken screws; the breakage acted as dynamization. One of the cases resulted in union of the fracture and the other continued without signs of union after 1 year of follow-up.

Three patients $(6.8 \%)$ contracted reflex sympathetic dystrophy, 2 from the Ender group and 1 from the LIN group. Sarangi et $\mathrm{al}^{37}$ reported a $30 \%$ rate of reflex sympathetic dystrophy in 60 patients with tibial fractures treated by 4 different methods: plaster device, plate, intramedullary nail, and external fixation device. The incidence rate did not differ for the methods used, and in most cases, the symptoms disappeared in less than 6 months. Our patients were treated with $25 \mathrm{mg} /$ day of amitriptyline, with regression of symptoms after an average of 4 months of treatment.

Lesion of the fibular nerve is reported as frequent in some specific studies on complications in treatment of tibial diaphyseal fractures with locked intramedullary nails, ${ }^{9,38}$ with an incidence rate reaching $30 \%$. In most studies, however, the incidence of lesions varies from $0 \%$ to $5.3 \%$. $^{1,2,21,35,39,40}$ Only $2(4.6 \%)$ of the patients in this study suffered neurological lesions, one from the Ender group, who had profound fibular nerve involvement, and the other from the LIN group, with a lesion on the ischial nerve (sciatica), both being diagnosed immediately after surgery. The latter case was probably provoked by excessive traction during treatment of the associated fracture of the femur on the same side.

Of the 5 patients in the LIN group whose fractures were dynamized, 3 via surgery and 2 due to breakage of the locking screws, only $3(60 \%)$ resulted in union. We believe that other procedures, such as nail replacement or use of a bone graft, are more adequate for delayed union in patients treated with LIN.

A correlation was seen between subtalar mobility limitation and the presence of ankle pain in the patients with loss of subtalar mobility ( $P=0.05$; Fisher test), but it is unknown if the limitation of movement is the cause or the consequence of the pain. The few studies found in the reviewed literature regarding the mobility of these 3 joints ${ }^{1,2,20,35}$ show that approximately $90 \%$ of patients recover normal joint amplitude.

Knee pain is a common finding in the LIN method, with reported incidence rates varying from $20 \%$ to $70 \%$. $^{2,9-11,27,41}$ Despite its frequency, the exact cause of this pain is unknown, but it appears that it is not related to the residual protrusion of the nail in the knee, ${ }^{41}$ nor to the access path used, whether through the patellar tendon or medially. ${ }^{11}$ Removal of the nail improves or eliminates the pain in most

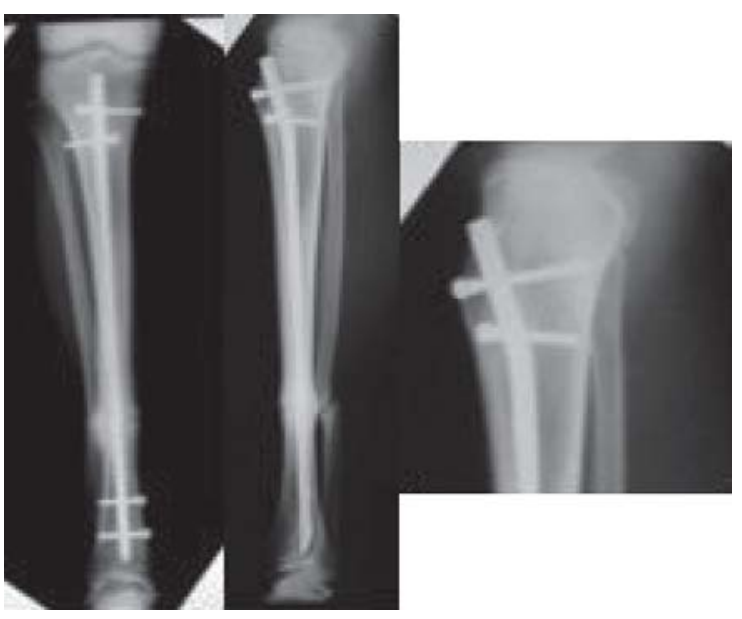

Figure 4 - Patient with healed fracture without evidence of nail extrusion but still suffering knee pain.

cases. ${ }^{10,41}$ In our cases in which a locked nail was used, $35.0 \%$ had knee pain after 1 year, but none had removal surgery (Figure 4).

Migration of Ender pins when used in treating tibia fractures is a frequent occurrence, with a rate of up to $47.5 \% .^{14}$ When a locked nail is used, discomfort is usually caused by the locking screws, with rates of about $13.6 \% .^{1}$ None of the cases in our study required surgery to remove the implants for these reasons.

The evaluation criteria used were those of Johner and Wruhs ${ }^{16}$ because they included both clinical aspects, such as pain, ability to walk and to perform heavy activities, neurovascular disturbances, and joint mobility, and radiographic aspects, such as union and existence of osteites and deformities. In most of the literature reviewed, few authors used well-defined criteria for radiographic and functional evaluation. ${ }^{3,5,27,32,33,39}$ With the exception of Gregory and Sanders, ${ }^{5}$ who used the criteria described by Johner and Wruhs, ${ }^{16}$ they all created their own evaluation systems, which, however, included several parameters also used by these authors.

Despite the fact that $70.0 \%$ of results for the LIN group were good or excellent compared to $56.5 \%$ in the Ender group, there was no significant difference between the two groups. We believe that the low number of good and excellent results found was due to the rigidity of the criteria defined by Johner and Wruhs, ${ }^{16}$ in which any limp, even insignificant and even when all other parameters are normal, results in a classification of fair. The fact that the final evaluation was performed only 1 year after surgery, when $58.1 \%$ of patients still suffer pain, also contributed to this finding. Patients classified as fair or poor, theoretically, could improve in terms of pain and gait with continued treatment, resulting in an improved evaluation. 


\section{CONCLUSIONS}

We conclude that in the management of tibial diaphyseal fractures of type $\mathrm{A}, \mathrm{B}$, and $\mathrm{C} 2$ (AO classification), both closed (Tscherne type 0,1 , and 2) and open (Gustilo degree I and II), treatment with the locked intramedullary nail provides clinical-surgical results similar to treatment with Ender pins, and that neither method prevents significant shortening of the tibia during the course of treatment.

\section{RESUMO}

Sakaki MH, Crocci AT, Zumiotti AV. Estudo comparativo entre a haste intramedular bloqueada e os pinos de Ender no tratamento das fraturas diafisárias da tíbia. CLINICS. 2007;62(4):455-64.

OBJETIVO: Comparar a haste intramedular bloqueada não-fresada com os pinos de Ender no tratamento das fraturas da diáfise da tíbia tipos A, B ou C2 da classificação AO, fechadas ou expostas graus I ou II de Gustilo.

MATERIAIS E MÉTODOS: 44 pacientes com fratura unilateral da diáfise da tíbia, tratados com HIB ou com pinos de Ender. Vinte pacientes foram tratados com uma haste intramedular bloqueada não fresada por acesso através do tendão patelar e com bloqueio estático; vinte e quatro pacientes com pinos de Ender introduzidos medial e lateralmente à tuberosidade da tíbia. Principais parâmetros analisados: tipo de redução, complicações, consolidação, deformidades, mobilidade articular, dor, marcha, capacidade para esforços, distúrbios neuro-vasculares e desconforto pelo material de síntese.

RESULTADOS: No seguimento de um ano, $90,0 \%$ das hastes intramedulares e 95,7\% dos pinos Ender dos pacientes apresentaram consolidação da fratura com tempo médio de 21,5 e 20,9 semanas, respectivamente. Os achados significantes foram: mobilidade da articulação subtalar menor nos pacientes tratados com pinos de Ender; dor no joelho mais freqüente nos pacientes tratados com HIB; encurtamento da tíbia nos dois grupos ao final de um ano de tratamento.

CONCLUSÕES: Os dois métodos são semelhantes no tratamento das fraturas da diáfise da tíbia tipos A, B e C2.

UNITERMOS: Fixação intramedular de fraturas. Fratura da tíbia/cirurgia. Pinos ortopédicos. Dispositivos de fixação ortopédica. Seguimentos. 
1. Court-Brown CM, Christie J, McQueen MM. Closed intramedullary tibial nailing. Its use in closed and type I open fractures. J Bone Joint Surg Br. 1990;72:605-11.

2. Hooper GJ, Keddell RG, Penny JD. Conservative management or closed nailing for tibial shaft fractures. A randomized prospective trial. J Bone Joint Surg Br. 1991;73:83-5

3. Alho A, Benterud JG, Hogevold HE, Ekeland A, Stromsoe K. Comparison of functional bracing and locked intramedullary nailing in the treatment of displaced tibial shaft fractures. Clin Orthop Relat Res. 1992;277:24350 .

4. Whittle AP, Russell TA, Taylor JC, Lavelle DG. Treatment of open fractures of the tibial shaft with the use of interlocking nailing without reaming. J Bone Joint Surg Am. 1992;74:1162-71.

5. Gregory P, Sanders R. The treatment of closed, unstable tibial shaft fractures with unreamed interlocking nails. Clin Orthop Relat Res. 1995;315:48-55.

6. Bone LB, Sucato D, Stegemann PM, Rohrbacher BJ. Displaced isolated fractures of the tibial shaft treated with either a cast or intramedullary nailing. An outcome analysis of matched pairs of patients. J Bone Joint Surg Am. 1997;79:1336-441.

7. Karladani AH, Granhed H, Edshage B, Jerre R, Styf J. Displaced tibial shaft fractures: a prospective randomized study of closed intramedullary nailing versus cast treatment in 53 patients. Acta Orthop Scand. 2000;71:160-7.

8. Riemer BL, DiChristina DG, Cooper A, Sagiv S, Butterfield SL, Burke CJ 3rd, et al. Nonreamed nailing of tibial diaphyseal fractures in blunt polytrauma patients. J Orthop Trauma. 1995;9:66-75.

9. Koval KJ, Clapper MF, Brumback RJ. Complications of reamed intramedullary nailing of the tibia. J Orthop Trauma. 1991;5:184-9.

10. Court-Brown CM, Gustilo T, Shaw AD. Knee pain after intramedullary tibial nailing: its incidence, etiology, and outcome. J Orthop Trauma. 1997; 11:103-5.

11. Toivanen JA, Vaisto O, Kannus P, Latvala K, Honkonen SE, Jarvinen MJ. Anterior knee pain after intramedullary nailing of fractures of the tibial shaft. A prospective, randomized study comparing two different nailinsertion techniques. J Bone Joint Surg Am. 2002;84:580-5.

12. Court-Brown CM, Will E, McQueen MM. Reamed or unreamed nailing for closed tibial fractures. A prospective study in Tscherne $\mathrm{C} 1$ fractures. J Bone Joint Surg Br. 1996;78:580-3.

13. Chiu FY, Lo WH, Chen CM, Chen TH, Huang CK. Treatment of unstable tibial fractures with interlocking nail versus Ender nail: a prospective evaluation. Zhonghua Yi Xue Za Zhi (Taipei). 1996;57:124-33.

14. Abramowitz A, Wetzler MJ, Levy AS, Whitelaw GP. Treatment of open tibial fractures with Ender rods. Clin Orthop Relat Res. 1993;293:24655 .

15. Hussain R, Umer M, Umar M. Treatment of tibial diaphyseal fractures with closed flexible intramedullary ender nails: 39 fractures followed for a period of two to seven years. J Pak Med Assoc. 2001;51:190-3.

16. Johner R, Wruhs O. Classification of tibial shaft fractures and correlation with results after rigid internal fixation. Clin Orthop Relat Res. 1983;178:725 .
17. Oestern HJ, Tscherne H. Pathophysiology and classification of soft tissue injuries associated with fractures. In: Tscherne H, Gotzen L, editors. Fractures with soft tissue injuries. Berlim: Springer-Verlag; 1984. p. 1-9.

18. Gustilo RB, Anderson JT. Prevention of infection in the treatment of one thousand and twenty-five open fractures of long bones: retrospective and prospective analyses. J Bone Joint Surg Am. 1976;58:453-8.

19. Mayer L, Werbie T, Schwab JP, Johnson RP. The use of Ender nails in fractures of the tibial shaft. J Bone Joint Surg Am. 1985;67:446-54.

20. Bone LB, Johnson KD. Treatment of tibial fractures by reaming and intramedullary nailing. J Bone Joint Surg Am. 1986;68:877-87.

21. Wiss DA. Flexible medullary nailing of acute tibial shaft fractures. Clin Orthop Relat Res. 1986;212:122-32.

22. Behrens F, Searls K. External fixation of the tibia. Basic concepts and prospective evaluation. J Bone Joint Surg Br. 1986;68:246-54.

23. Clifford RP, Beauchampo CG, Kellam JF. Plate fixation of open fractures of the tibia. J Bone Joint Surg Br. 1988;70:644-48.

24. Henley MB Intramedullary devices for tibial fracture stabilization. Clin Orthop Relat Res. 1989;240:87-96.

25. Singer RW, Kellam JF. Open tibial diaphyseal fractures. Results of unreamed locked intramedullary nailing. Clin Orthop Relat Res. $1995 ; 315-114-8$

26. Tu YK, Lin CH, Su JI, Hsu DT, Chen RJ. Unreamed interlocking nail versus external fixator for open type III tibia fractures. J Trauma. $1995 ; 39: 361-7$

27. Schandelmaier P, Krettek C, Rudolf J, Kohl A, Katz BE, Tscherne H. Superior results of tibial rodding versus external fixation in grade $3 \mathrm{~B}$ fractures. Clin Orthop Relat Res. 1997;342:164-72.

28. Grecco MAS, Prado Junior I, Rocha MA, Barros JW. Estudo epidemiológico das faturas diafisárias de tíbia. Acta Ortop Bras. 2002;10:10-17.

29. Pankovich AM, Tarabishy IE, Yelda S. Flexible intramedullary nailing of tibial-shaft fractures. Clin Orthop Relat Res. 1981;160:185-95.

30. Merianos P, Papagiannakos K, Scretas E, Smyrnis P. Ender nails for segmental tibial fracture. Early weight bearing in 22 cases. Acta Orthop Scand. 1988;59:297-301

31. Henley MB, Chapman JR, Agel J, Harvey EJ, Whorton AM, Swiontkowski MF. Treatment of type II, IIIA, and IIIB open fractures of the tibial shaft: a prospective comparison of unreamed interlocking intramedullary nails and half-pin external fixators. J Orthop Trauma. 1998;12:1-7.

32. French B, Tornetta P 3rd. High-energy tibial shaft fractures. Orthop Clin North Am. 2002:33:211-30.

33. Holbrook JL, Swiontkowski MF, Sanders R. Treatment of open fractures of the tibial shaft: Ender nailing versus external fixation. A randomized, prospective comparison. J Bone Joint Surg Am. 1989;71:1231-8.

34. Blachut PA, O’Brien PJ, Meek RN, Broekhuyse HM. Interlocking intramedullary nailing with and without reaming for the treatment of closed fractures of the tibial shaft. A prospective, randomized study. J Bone Joint Surg Am. 1997;79:640-6. 
35. Merianos P, Cambouridis P, Smyrnis P. The treatment of 143 tibial shaft fractures by Ender's nailing and early weight-bearing. J Bone Joint Surg Br. 1985;67:576-80.

36. Keating JF, O'Brien PJ, Blachut PA, Meek RN, Broekhuyse HM. Locking intramedullary nailing with and without reaming for open fractures of the tibial shaft. J Bone Joint Surg Am. 1997;79:334-41.

37. Sarangi PP, Ward AJ, Smith EJ, Staddon GE, Atkins RM. Algodystrophy and osteoporosis after tibial fractures. J Bone Joint Surg Br. 1993;75:4502.

38. Williams J, Gibbons M, Trundle H, Murray D, Worlock P. Complications of nailing in closed tibial fractures. J Orthop Trauma. 1995;9:476-81.
39. Ekeland A, Thoresen BO, Alho A, Stromsoe K, Folleras G, Haukebo A. Interlocking intramedullary nailing in the treatment of tibial fractures. A report of 45 cases. Clin Orthop Relat Res. 1988;231:205-15.

40. Robinson CM, O’Donnell J, Will E, Keating JF. Dropped hallux after the intramedullary nailing of tibial fractures. J Bone Joint Surg Br. 1999;81:481-4.

41. Keating JF, Orfaly R, O’Brien PJ. Knee pain after tibial nailing. J Orthop Trauma. 1997;11:10-3 